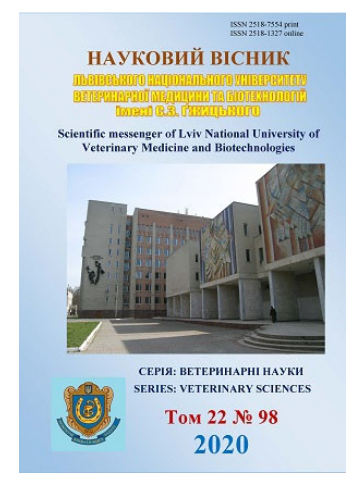

Науковий вісник Дьвівського націонадьного університету ветеринарної медицини та біотехнологій імені С.3. Гжицького. Серія: Ветеринарні науки

\author{
Scientific Messenger of Lviv National University \\ of Veterinary Medicine and Biotechnologies. \\ Series: Veterinary sciences
}

UDC 619:614.31:637.5:661.41

\title{
Veterinary-sanitary evaluation of high-class boiled sausage "Likarska"
}

\author{
M. S. Khimich ${ }^{1}$, V. Z. Salata ${ }^{2}$, O. T. Piven ${ }^{1}$, R. V. Salata ${ }^{2}$ Zn. B. Koreneva ${ }^{1}$, O. V. Naidich ${ }^{1}$ \\ ${ }^{1}$ Odessa State Agrarian University, Odessa, Ukraine \\ ${ }^{2}$ Stepan Gzhytskyi National University of Veterinary Medicine and Biotechnologies Lviv, Ukraine
}

Article info

Received 13.03.2020

Received in revised form 14.04.2020

Accepted 15.04.2020

Odessa State Agrarian University, Panteleymonyvska Str., 13, Odessa, 65012, Ukraine.

Tel.: +38-067-799-21-13

E-mail: khimichms@gmail.com

Stepan Gzhytskyi National University of Veterinary Medicine and Biotechnologies Lviv

Pekarska Str., 50, Lviv, 79010, Ukraine.
Khimich, M. S., Salata, V. Z., Piven, O. T., Salata, R. V., Koreneva, Zn. B., \& Naidich, O. V. (2020). Veterinary-sanitary evaluation of high-class boiled sausage "Likarska". Scientific Messenger of Lviv National University of Veterinary Medicine and Biotechnologies. Series: Veterinary sciences, 22(98), 36-41. doi: 10.32718/nvlvet9806

Today in Ukraine the part of the sausage production segment is about $30 \%$ of all ready meat products. The boiled sausages play the main role among them. About $65 \%$ of general assortment belongs to them among consumers. Safety and quality assurance of sausage is impossible without the conformity of requirements and recipes. The SSTU 4436:2005 "Boiled sausages, sausages, meat breads. General specifications" regulates them in Ukraine. However, today is observed the significant growth of sausages assortment, which are produced by recipes of producers. It allows them to use in production different nutritional supplements, replacement of raw materials, etc. Recent publications of experts shows that about $80 \%$ of food products are falsified. The most common is assortment falsification. Therefore, the purpose of our study was to analyze the conformity of quality and safety parameters of high-class boiled sausage "Likarska" from the different producers to the SSTU 4436:2005 "Boiled sausages, sausages, meat breads. General specifications". The materials of our study were the samples of high-class boiled sausage "Likarska” from the several domestic producers: LLC “Alan” (Dnipro), JV "Vekka” LLC (Odessa region, Lyman district, Blagodatne), LLC "Globino Meat Factory” (Poltava region, Globin district, Globino), LLC "Khodoriv Meat Factory" (Lviv region, Zhydachiv district, Khodoriv). The samples were selected by the control purchase in Odessa trading network ("METRO”, "Silpo", "FOZZY") and in Lviv trading network ("Vopak", "METPO”, "Silpo”). As a result 20 samples were selected and investigated in general. The studies were conducted during 2019-2020 on the basis of Multidisciplinary Laboratory of Veterinary Medicine (Faculty of Veterinary Medicine and Biotecnologies of Odessa State Agrarian University) and on the basis of the laboratory of Department of Veterinary-Sanitary Inspection (Stepan Gzhytskyi National University of Veterinary Medicine and Biotechnologies, Lviv). We selected the samples, carried out sanitary assessments of sausages, determined the microbiological parameters in accordance with applicable regulations. We determined the physico-chemical parameters using the device FoodScan, radionuclides content - by $\beta$ - $\gamma$-spermometry and the general toxicity - using the express method with the infusorium Colpoda steinii. According to the results of analysis of labeling we found out that the packaging (label) of all producers which were studied contains the basic production and consumer information. The analysis of the organoleptical, microbiological indicators and the radionuclides content of samples which were studied established their compliance with the requirement of SSTU 4436:2005. The total toxicity of sausages also wasn't established. At the same time the analysis of physico-chemical parameters revealed non-compliance with SSTU 4436:2005 requirements by the mass fraction of protein in sausage "Likarska", which was produced by JV "Vekka” LLC (10.95 $\pm 0.01 \%)$ and LLC “Globino Meat Factory”" (10.68 $\pm 0.02 \%)$.

Key words: boiled sausages, meat products, quality parameters, safety parameters, veterinary-sanitary control.

\section{Ветеринарно-санітарна оцінка ковбаси вареної вищого сорту “Лікарська”}

\author{
М. С. Хімич ${ }^{1}$, В. 3. Салата², О. Т. Півень ${ }^{1}$, Р. В. Салата², Ж. Б. Коренєва ${ }^{1}$, О. В. Найдіч ${ }^{1}$
}


${ }^{1}$ Одеський державний аграрний університет, м. Одеса, Украӥна

${ }^{2}$ Львівський національний університет ветеринарної медицини та біотехнологій імені С. 3. Гжицького, м. Львів, Україна

Сьогодні в Украӥні частка сегменту виробництва ковбас становить близько 30 \% в обсязі готової м'ясної продукції, а серед них провідну роль займають варені ковбаси, на споживання яких припадає до 65 \% від загального асортименту. Забезпечення якості та безпеки ковбас, неможливе без дотримання вимог і рецептур, які в Украӥні регламентує ДСТУ 4436:2005 “Ковбаси варені, сосиски, сардельки, хліби м'ясні. Загальні технічні умови”. Проте сьогодні спостерігається суттєвий ріст асортименту ковбас, вироблених за реиептурами, розробленими безпосередньо виробниками, що дозволяє їм використовувати при виробництві різноманітні харчові добавки, заміну сировини тощчо. Останні публікаиії фахівиів свідчать, що близько 80 \% харчової продукиї фальсифіковано $і$ найпотиренішою є асортиментна фальсифікаиія. Тому метою намого дослідження було проаналізувати відповідність показників якості та безпечності вареної ковбаси вищого сорту “Лікарська" різних виробників ДСТУ 4436:2005 “Ковбаси варені, сосиски, сардельки, хліби м'ясні. Загальні технічні умови”. Матеріалом наших досліджень були зразки вареної ковбаси вищого сорту “Лікарська” декількох вітчизняних виробників: ТОВ “Алан” (м. Дніпро), СП “Векка” ТОВ (Одеська область, Лиманський район, с. Благодатне), ТОВ “Глобинський м'ясокомбінат” (Полтавська область, Глобинський район, м. Глобине), ТзОВ “Ходорівський м'ясокомбінат” (Львівська область, Жидачівський район, м. Ходорів). Зразки відібрали шлляхом контрольної закупки у торгівельній мережі міст Одеси (“МЕТРО", “Сільпо”, “FOZZY”) та Львова (“Вопак”, “МЕТРО”, “Сільпо”). Всього було відібрано і досліджено 20 зразків. Дослідження проводились впродовж 2019-2020 рр. на базі багатопрофільної лабораторії факультету ветеринарної медииини та біотехнологій Одеського державного аграрного університету і лабораторії кафедри ветеринарно-санітарного інспектування Львівського університету ветеринарної медицини та біотехнологій імені С. 3. Гжицького. Відбір проб і сенсорну оиінку ковбас, визначення мікробіологічних показників проводили згідно з чинною нормативною документаиією, визначення фізико-хімічних показників - за допомогою приладу FооdScan, вміст радіонуклідів методом $\beta$-ү-спертрометрії; загальну токсичність - експрес-методом 3 використанням інфузорії Colpoda steinii. $3 a$ результатами аналізу маркування встановлено, що пакування (етикетка) всіх досліджених виробників містить основну виробничу i споживчу інформацію. Аналіз органолептичних і мікробіологічних показників та вмісту радіонуклідів досліджених зразків встановив їхню відповідність вимогам ДСТУ 4436:2005. Загальної токсичності ковбас також не виявлено. Натомість аналіз фізико-хімічних показників виявив невідповідність вимогам ДСТУ 4436:2005 за вмістом масової частки білка ковбаси “Лікарська" виробництва СП “Векка” ТОВ (10.95 $\pm 0.01 \%)$ і ТОВ “Глобинський м'ясокомбінат” (10.68 $0.02 \%)$.

Ключові слова: ветеринарно-санітарний контроль, м'ясні продукти, варена ковбаса, показники якості, показники безпечності.

\section{Вступ}

М'ясна промисловість постачає для населення широкий асортимент продукції, а ковбасні вироби належать до числа найбільш розповсюджених видів м'ясопродуктів. Сьогодні частка сегменту виробництва ковбас в загальному обсязі продукції м'ясопереробної галузі складає 14,5 \%, а в обсязі готової м'ясної продукції - близько 30 \% (Koniak, 2012; Sljoz, 2017; Rakhman et al., 2018; Poltoratskaia, 2018).

Аналіз сучасного ринку свідчить, що ковбасна продукція нині на четвертому місці в шкалі продуктів, що користуються постійним попитом у населення, а найбільшу частку серед ковбасних виробів України займають варені ковбаси, на споживання яких припадає до $65 \%$ від загального асортименту. Зазначені вироби традиційно користуються у населення особливою популярністю, оскільки вони володіють значними споживчими перевагами та харчовою цінністю (Koniak, 2012; Fursik \& Strashynskyi, 2017; Rakhman et al., 2018; Romaniuk, 2019).

Але важливо враховувати, що головною умовою можливості реалізації продукту харчування залишається його безпечність при споживанні людиною (Kolesnyk et al., 2014; Verbelchuk \& Koshlan, 2016; Dashkovskyi \& Salata, 2016; Bohatko et al., 2017).

Забезпечення якості та безпеки ковбас неможливе без дотримання вимог і рецептур, передбачених для тих чи інших харчових продуктів. Такі вимоги в Україні регламентує ДСТУ, проте в останні роки спостерігається суттєвий ріст асортименту ковбасних виробів, які випускаються за рецептурою, що була розроблена самим виробником (ТУ). Розробка власних ТУ дозволяє виробникам застосовувати при виробництві м'ясопродуктів різноманітні харчові добавки, замінювати натуральну сировину соєю, високосортне м'ясо низькосортним тощо. Так, останні публікації фахівців свідчать, що близько 80 \% харчової продукції фальсифіковано за одним або кількома показниками, а найпоширенішою $\epsilon$ асортиментна фальсифікація (Burhu \& Khrul, 2010; Dovgan', 2013; Verbelchuk \& Koshlan, 2016; Bohatko et al., 2017; Nesterova \& Moskvicheva, 2017; Tul'ceva, 2017; Ushakov, 2017; Ievtushenko, 2018; Varchenko \& Herasymenko, 2019).

Мета та завдання дослідження. Враховуючи вищевикладене, метою нашого дослідження було проаналізувати відповідність показників якості та безпечності вареної ковбаси вищого сорту "Лікарська" різних виробників ДСТУ 4436:2005 “Ковбаси варені, сосиски, сардельки, хліби м'ясні. Загальні технічні умови” з виконанням таких завдань:

- проаналізувати якість маркування;

- провести аналіз якісних (органолептичних i фізико-хімічних) показників;

- провести аналіз окремих показників безпечності (мікробіологічні показники, вміст радіонуклідів, загальна токсичність).

\section{Матеріал і методи досліджень}

Матеріалом наших досліджень були зразки вареної ковбаси вищого сорту “Лікарська" декількох 
вітчизняних виробників: ТОВ “Алан” (м. Дніпро), СП "Векка" ТОВ (Одеська область, Лиманський район, с. Благодатне), ТОВ “Глобинський м'ясокомбінат” (Полтавська область, Глобинський район, м. Глобине), ТзОВ “Ходорівський м’ясокомбінат” (Львівська область, Жидачівський район, м. Ходорів). Зразки відібрали шляхом контрольної закупки у торгівельній мережі міст Одеси ("METPO", "Сільпо", "FOZZY”) та Львова (“Вопак”, "МЕТРО”, “Сільпо”). Всього було відібрано і досліджено 20 зразків.

Дослідження проводились впродовж 20192020 pp. на базі багатопрофільної лабораторії факультету ветеринарної медицини та біотехнологій Одеського державного аграрного університету та лабораторії кафедри ветеринарно-санітарного інспектування Львівського університету ветеринарної медицини та біотехнологій імені С. 3. Гжицького.

Відбір проб і сенсорну оцінку ковбас проводили згідно $з$ ДСТУ 4823.2:2007; визначення фізико- хімічних показників (масові частки білка, жиру, вологи, натрію хлориду, вміст золи і колагену) - за допомогою приладу FoodScan; мікробіологічні показники визначали згідно з ГОСТ 10444.15-94 (вміст КМАФАнМ), ГОСТ 30518-97 (наявність БГКП коліформні бактерії), ГОСТ 29185-91 (наявність сульфіторедукуючих клостридій у 1 г продукту), ГОСТ 10444.2-94 (наявність стафілококів у 1 г продукту), ДСТУ ЕN 12824-2004 (наявність сальмонел у 25 г продукту), ДСТУ ISO 11290-2-2003 (наявність лістерій); вміст радіонуклідів ${ }^{137} \mathrm{Cs}$ та ${ }^{90} \mathrm{Sr}-$ методом $\beta$ - $\gamma$-спертрометрії; загальну токсичність експрес-методом $з$ використанням інфузорії Colpoda steinii.

\section{Результати та обговорення}

Результати аналізу якості та інформативності маркування дослідних ковбас наведені в таблиці 1.

\section{Таблиця 1}

Інформація для споживача, вказана на пакуванні вареної ковбаси “Лікарська"

\begin{tabular}{|c|c|c|c|c|}
\hline \multirow[b]{2}{*}{ Показники } & \multicolumn{4}{|c|}{ Виробник } \\
\hline & $\begin{array}{l}\text { ТОВ “Алан” } \\
\text { (ТМ “АЛАН”) }\end{array}$ & $\begin{array}{c}\text { СП “Векка” } \\
\text { ТОВ }\end{array}$ & $\begin{array}{c}\text { TОВ “Глобинський } \\
\text { м'ясокомбінат” } \\
\text { (ТМ “Глобино”) }\end{array}$ & $\begin{array}{c}\text { ТзОВ } \\
\text { "Ходорівський } \\
\text { м'ясокомбінат" }\end{array}$ \\
\hline Оболонка & фіброуз & натуральна (синюга) & білкова & білкозин \\
\hline $\begin{array}{l}\text { Документ, } \\
\text { відповідно до } \\
\text { якого продукт } \\
\text { вироблено }\end{array}$ & ДСТУ 4436:2005 & ДСТУ 4436:2005 & ДСТУ 4436:2005 & ДСТУ 4436:2005 \\
\hline Склад & 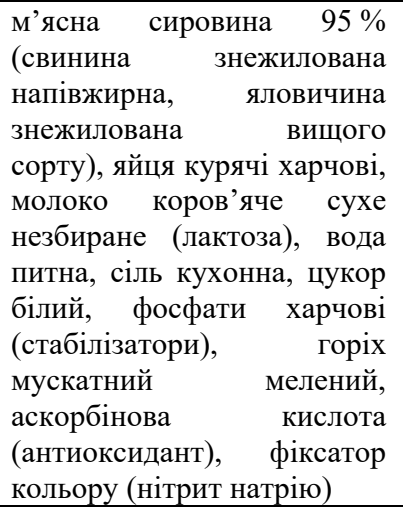 & 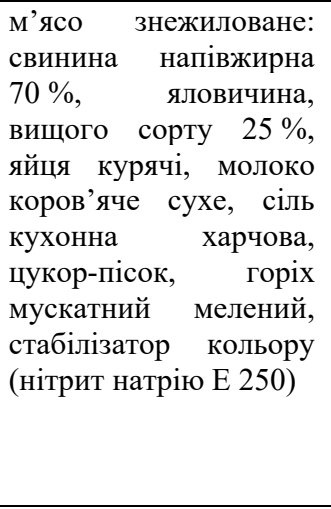 & 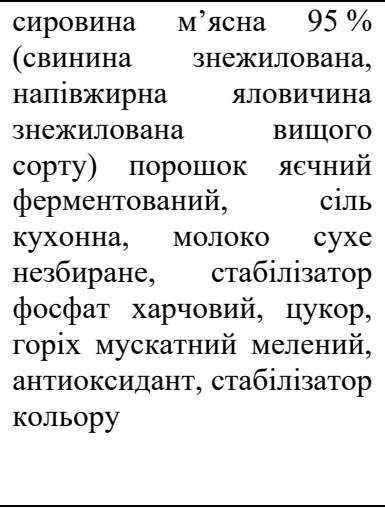 & 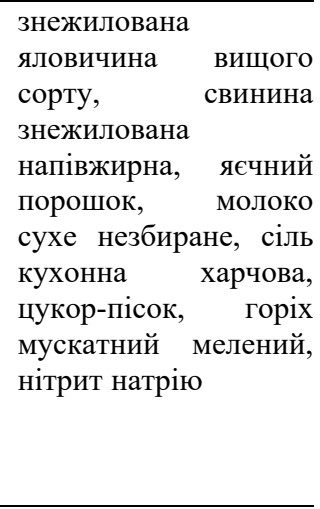 \\
\hline $\begin{array}{l}\text { Поживна } \\
\text { (харчова) } \\
\text { цінність, } 100 \text { г }\end{array}$ & $\begin{array}{l}\text { білки - не менше } 13,0 \text { г; } \\
\text { жири - не більше } 22,0 \text { г }\end{array}$ & $\begin{array}{l}\text { білок } 13 \text { г; } \\
\text { жири } 22 \text { г; }\end{array}$ & $\begin{array}{c}\text { білок } 13,0 \text { г; жир 22,0 г; } \\
\text { вуглеводи 1,0 г }\end{array}$ & $\begin{array}{l}\text { білки - 13,0 } \\
\text { жири - 22,0 }\end{array}$ \\
\hline $\begin{array}{l}\text { Енергетична } \\
\text { цінність на } 100 \text { г }\end{array}$ & 250,0 Ккал & 250,0 Ккал & 250,0 Ккал & 250,0 Ккал \\
\hline $\begin{array}{l}\text { Умови } \\
\text { зберігання та } \\
\text { термін } \\
\text { придатності }\end{array}$ & $\begin{array}{l}\text { за відносної вологості } \\
\text { повітря не вище ніж } 75 \% \text { - } \\
78 \% \text {, за температури від } \\
0{ }^{\circ} \mathrm{C} \text { до } 6{ }^{\circ} \mathrm{C} \text { не більше ніж } \\
15 \text { діб, за умови цілісності } \\
\text { упаковки }\end{array}$ & $\begin{array}{c}\text { при t } 0 \ldots+6{ }^{\circ} \mathrm{C} \\
\text { вл. } 75-78 \% \\
\text { Вжити до: ....... }\end{array}$ & $\begin{array}{l}\text { Температура зберігання } \\
\text { від } 0 \text { до } 6{ }^{\circ} \mathrm{C} . \text { Відносна } \\
\text { вологість від } 75 \% \text { до } \\
78 \% . \quad 10 \text { діб. Термін } \\
\text { зберігання без пакування } \\
3 \text { доби }\end{array}$ & $\begin{array}{l}\text { При температурі від } 0 \\
\text { до } 6{ }^{\circ} \mathrm{C} \text { та відносній } \\
\text { вологості повітря 75- } \\
78 \% \text { у вакуумній } \\
\text { упаковці } \\
\text { виробом - } 15 \text { діб } \\
\end{array}$ \\
\hline $\begin{array}{l}\text { Адреса } \\
\text { виробника } \\
\text { (потужностей } \\
\text { виробництва) } \\
\end{array}$ & 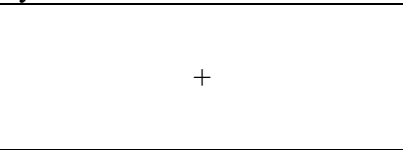 & + & + & בr \\
\hline
\end{tabular}


Як ми можемо бачити, всі розглянуті нами виробники надають споживачу інформацію щодо нормативного документу, згідно 3 яким продукт виготовлено, складу продукту, його поживної та енергетичної цінності, умов зберігання і термінів споживання та вказують юридичну адресу виробника або виробничих потужностей. Але водночас у нас виникли зауваження щодо якості поданої на етикетках інформації. Так, на етикетці ковбаси, виробленої ТзОВ “Ходорівський м'ясокомбінат” не вказано відсотка м'ясної сировини; на етикетці продукції ТОВ “Алан” не вказано точного вмісту білків і жирів, а лише “...не менше..., ...не більше...”; етикетка ковбаси СП "Векка" містить недостатньо вичерпну інформацію щодо умов зберігання і термінів споживання продукту.

Далі ми провели сенсорний аналіз ковбас. Встановлено, що зовнішній вигляд всіх досліджених зразків відповідав вимогам ДСТУ 4436:2005 - батони ковбас мали чисту суху поверхню без пошкодження оболонки, напливів фаршу, злипання, бульйонних та жирових набряків. Однак зазначимо, що за рахунок різних оболонок візуально привабливість виробів різнилась, що вплинуло на бальну оцінку.

Після зовнішнього огляду ми розрізали батони ковбас i проводили сенсорну оцінку, визначаючи консистенцію, колір і вигляд фаршу на розрізі, запах і смак зразків ковбас.

Зразки ТМ “Алан” мали пружну та ніжну консистенцію; світло-рожевий колір фаршу, 3 незначною кількістю дрібних порожнин; приємний м'ясний запах; смак в міру солоний 3 помірною кількістю спецій і молочним присмаком. За проби варки бульйон був ледь рожевий, напівпрозорий, 3 поодинокими краплинками жиру.

Зразки виробів СП “Векка" були пружної консистенції; фарш на розрізі був однорідним i рожевим; запах був вираженим, ніжним, специфічним; смак виражений приємний, відчувається помірна кількість спецій, в міру солоний. Бульйон мав насичений рожево-помаранчевий колір i значну кількість краплинок жиру.

Зразки ТМ “Глобино” мали пружну, але жорсткувату консистенцію; фарш на розрізі однорідний, світло-рожевого, навіть сіруватого кольору; запах зразків насичений; смак виражений, солонуватий відчувається високий вміст спецій. Бульйон був блідо-рожевим, напівпрозорим, 3 незначною кількістю краплинок жиру на поверхні.

Зразки ковбаси виробництва ТзОВ “Ходорівський м'ясокомбінат” були пружної ніжної консистенції; фарш на розрізі був однорідним світло-рожевим; запах - приємний, специфічний, м'ясний; смак приємний, в міру солоний 3 помірною кількістю спецій. Бульйон був напівпрозорим блідо-рожевим 3 поодинокими краплинками жиру.

Узагальнені результати сенсорної оцінки варених ковбас показані на рисунку 1.

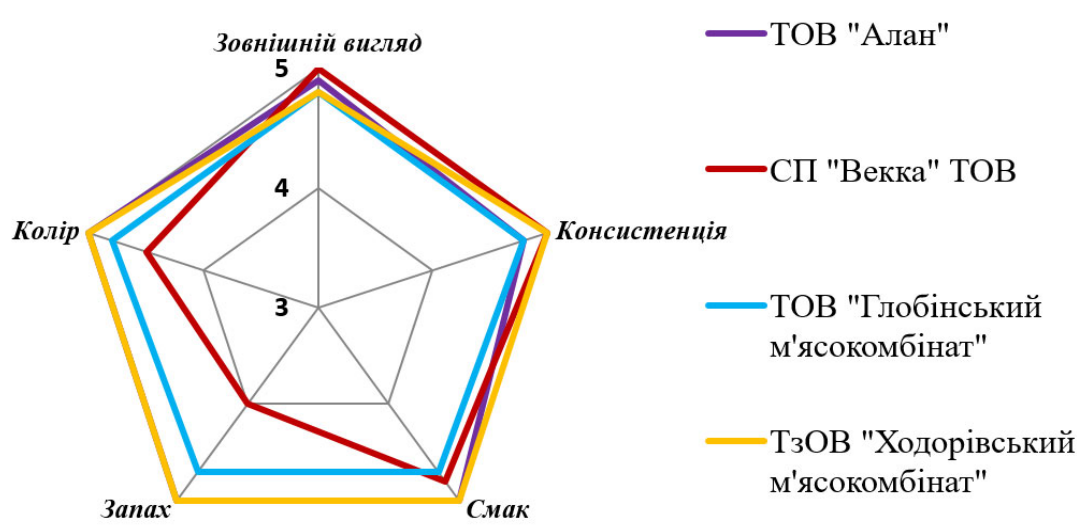

Рис. 1. Результати сенсорної оцінки вареної ковбаси “Лікарська"

3 рисунка видно, що найвищу кількість балів 24,8 - набрала ковбаса "Лікарська" виробництва ТзОВ “Ходорівський м'ясокомбінат”, ковбаса ТМ “Алан” отримала 24,7 бала, ТМ "Глобино” 23,8 бала та СП "Векка" ТОВ - 23,3 бала. Але незважаючи на різну кількість балів, які набрали вироби різних виробників, всі досліджені зразки відповідали вимогам ДСТУ за органолептичними показниками.

Надалі ми визначали фізико-хімічні показники ковбас (табл. 2). 3 таблиці видно, що найвищий вміст масової частки білка встановлено у ковбасах виробництва ТОВ “Алан” - 12,91 $\pm 0,08$ \% і ТзОВ “Ходорівський м'ясокомбінат" - 12,88 $\pm 0,11 \%$, і 3 урахуванням похибки можна вважати, що ці зразки відповідають вимогам ДСТУ за даним показником. Що ж до ковбас решти виробників, то в них показник масової частки білка коливався в межах 10,68 $\pm 0,02-$ $10,95 \pm 0,01 \%$, що значно нижче від встановленого стандартом.

Показники масової частки жиру і натрію хлориду, залежно від виробника, коливались в межах $17,36 \pm 0,08-19,64 \pm 0,05 \%$ і 1,54 $\pm 0,09-2,14 \pm 0,02$ відповідно, що повністю відповідає вимогам стандарту.

Щодо масової частки вологи, то найвищий показник встановлено у зразків ТМ "Глобино" $66,11 \pm 0,04 \%$, що перевищує допустимий стандартом норматив. Водночас решта виробів відповідали вимогам ДСТУ. 
Ще два визначені нами показники - вміст золи і колагену - ДСТУ не регламентує, але їх визначення передбачено програмою приладу Food Scan, який налаштовано на контроль під час технологічного процесу виробництва. За результатами вимірювань найвищий вміст золи 2,67 $\pm 0,11 \%$ встановлено у зразках ковбас виробництва ТМ “Алан”, а найнижчий $2,37 \pm 0,01 \%-$ у виробах ТМ “Глобино”. Щодо вмісту колагену, то тут ситуація протилежна найвищий вміст $2,65 \pm 0,01 \%$ виявлено у ковбасі ТМ “Глобино”, а найнижчий $1,76 \pm 0,07 \%-$ у виробах ТМ “Алан”.

Таким чином, узагальнюючи результати досліджень фізико-хімічних показників ковбас, ми встановили, що вироби ТОВ “Алан” і ТзОВ “Ходорівський м'ясокомбінат" відповідають вимогам стандарту і $є$ якісними. Натомість ковбаси СП "Векка" i ТМ "Глобино" за рядом показників не відповідають вимогам ДСТУ 4436:2005.

За результатами оцінки мікробіологічних показників (табл. 3), зразки ковбас усіх виробників відповідали вимогам ДСТУ 4436:2005, а саме: вміст КМАФАнМ коливався в межах $(1,9 \pm 021) \times 10^{2}-(2,3 \pm$ $0,02) \times 10^{2} \quad$ КУО $/ \mathrm{cm}^{3} ;$ БГКП (коліформні бактеріі), сульфіторедукуючі клостридії та стафілококи в 1 г та сальмонели і лістерії в 25 г продукту не виявляли.

Дослідження вмісту радіонуклідів ${ }^{137} \mathrm{Cs}$ та ${ }^{90} \mathrm{Sr}$ (табл. 4) встановили, що їхній вміст не перевищував допустимих рівнів, установлених ДСТУ 4436:2005.

Таблиця 2

Фізико-хімічні показники ковбаси “Лікарська" $\mathrm{M} \pm \mathrm{m}, \mathrm{n}=20$

\begin{tabular}{lccccc}
\hline \multirow{2}{*}{$\begin{array}{c}\text { Найменування } \\
\text { показника }\end{array}$} & \multirow{2}{*}{$\begin{array}{c}\text { Вимоги } \\
\text { ДСТУ }\end{array}$} & \multirow{2}{*}{ ТОВ “Алан” } & $\begin{array}{c}\text { СП “Векка” } \\
\text { ТОВ }\end{array}$ & $\begin{array}{c}\text { ТОВ “Глова марка } \\
\text { м’ясокомбінат” }\end{array}$ & $\begin{array}{c}\text { ТзОВ “Ходорівський } \\
\text { м’ясокомбінат” }\end{array}$ \\
\hline Масова частка білка, \% & не менше ніж 13 & $12,91 \pm 0,08$ & $10,95 \pm 0,01$ & $10,68 \pm 0,02$ & $12,88 \pm 0,11$ \\
Масова частка жиру, \% & не більше ніж 22 & $17,36 \pm 0,08$ & $19,64 \pm 0,05$ & $17,52 \pm 0,08$ & $18,99 \pm 0,12$ \\
Масова частка вологи, \% не більше ніж 65 & $65,11 \pm 0,09$ & $64,09 \pm 0,11$ & $66,11 \pm 0,04$ & $64,19 \pm 0,01$ \\
Масова частка кухонної & не більше 2,5 & $2,03 \pm 0,05$ & $2,14 \pm 0,04$ & $1,54 \pm 0,09$ & $2,0 \pm 0,06$ \\
солі, \% & - & $2,67 \pm 0,11$ & $2,66 \pm 0,13$ & $2,37 \pm 0,01$ & $2,53 \pm 0,05$ \\
Зола & - & $1,76 \pm 0,07$ & $2,20 \pm 0,04$ & $2,65 \pm 0,01$ & $1,85 \pm 0,02$ \\
Колаген & - &
\end{tabular}

Таблиця 3

Мікробіологічні показники ковбаси “Лікарська", $\mathrm{M} \pm \mathrm{m}, \mathrm{n}=20$

\begin{tabular}{lccccc}
\hline \multirow{2}{*}{ Найменування показника } & $\begin{array}{c}\text { Вимоги } \\
\text { ДСТУ }\end{array}$ & ТОВ “Алан” & $\begin{array}{c}\text { СП “Векка” } \\
\text { ТОВ }\end{array}$ & $\begin{array}{c}\text { ТОВ “Глобинський } \\
\text { м'ясокомбінат” }\end{array}$ & $\begin{array}{c}\text { ТзОВ “Ходорівський } \\
\text { м'ясокомбінат” }\end{array}$ \\
\cline { 2 - 5 } $\begin{array}{l}\text { Кількість МАФАнМ, } \\
\text { КУО/см }\end{array}$ & $\begin{array}{l}\text { не більше } \\
\text { ніж } 1,0 \times 10^{3}\end{array}$ & $(2,3 \pm 0,02) \times 10^{2}$ & $(1,9 \pm 021) \times 10^{2}$ & $(2,2 \pm 0,65) \times 10^{2}$ & $(2,1 \pm 0,13) \times 10^{2}$ \\
\hline
\end{tabular}

Таблиця 4

Вміст радіонуклідів у ковбасі “Лікарська", $\mathrm{M} \pm \mathrm{m}, \mathrm{n}=20$

\begin{tabular}{lccccc}
\hline \multirow{2}{*}{$\begin{array}{c}\text { Найменування } \\
\text { показника }\end{array}$} & \multirow{2}{*}{$\begin{array}{c}\text { Вимоги } \\
\text { ДСТУ }\end{array}$} & ТОВ “Алан” & СП “Векка” ТОВ & $\begin{array}{c}\text { ТОВ “Глобинський } \\
\text { м'ясокомбінат” }\end{array}$ & $\begin{array}{c}\text { ТзОВ “Ходорівський } \\
\text { м’ясокомбінат” }\end{array}$ \\
\cline { 5 - 6 } & 200 & $10,51 \pm 0,31$ & $6,53 \pm 0,13$ & $9,77 \pm 0,71$ & $4,35 \pm 0,41$ \\
${ }^{137} \mathrm{Cs}$, Бк/кг & 20 & $1,15 \pm 0,4$ & $0,68 \pm 0,32$ & $0,98 \pm 0,2$ & $0,49 \pm 0,19$ \\
\hline${ }^{90} \mathrm{Sr}$, Бк/кг & & &
\end{tabular}

Загальної токсичності досліджених виробів ми також не виявляли.

\section{Висновки}

1. Маркування ковбаси “Лікарська" виробництва ТОВ “Алан”, СП "Векка" ТОВ, ТОВ “Глобинський м'ясокомбінат”, ТзОВ “Ходорівський м'ясокомбінат” містить основну виробничу і споживчу інформацію та відповідає вимогам законодавства.

2. Ковбаса "Лікарська" всіх досліджених виробників відповідала вимогам, встановленим ДСТУ 4436:2005 “Ковбаси варені, сосиски, сардельки, хліби м'ясні. Загальні технічні умови" за органолептичними і мікробіологічними показниками та вмістом радіонуклідів.

3. Загальної токсичності у жодному з дослідних зразків ковбас не виявлено.

4. За дослідженими фізико-хімічними показниками - ковбаса "Лікарська" виробництва ТОВ "Алан" i ТзОВ "Ходорівський м'ясокомбінат" відповідала вимогам ДСТУ 4436:2005. Натомість у виробах СП "Векка" ТОВ і ТОВ "Глобинський м'ясокомбінат" встановлено занижений вміст масової частки білка. 


\section{References}

Bohatko, N. M., Bohatko, L. M., Salata, V. Z., Semaniuk, V. I., Serdiukov, Ya. K., \& Shchurevych, H. P. (2017). Veterynarno-sanitarnyi kontrol bezpechnosti ta yakosti miasnykh produktiv. Naukovyi visnyk LNUVMBT imeni S.Z. Gzhytskoho, 19(73), 7-10. http://nbuv.gov.ua/UJRN/nvlnuvmbvn_2017_19_73_4 (in Ukrainian).

Burhu, Yu. H., \& Khrul, V. S. (2010). Tovaroznavcha kharakterystyka varenykh kovbas. Naukovyi visnyk Poltavskoho universytetu ekonomiky i torhivli, 1(46), 60-63 (in Ukrainian).

Dashkovskyi, O. O., \& Salata, V. Z. (2016). Analiz ryzykiv ta krytychnykh kontrolnykh tochok (NASSR), pry vyrobnytstvi miasnykh kovbas na PP "Ctryiski delikatesy”. Naukovyi visnyk LNUVMBT imeni S. Z. Gzhytskoho, 18, 3(70), 83-87. doi: 10.15421/nvlvet7019 (in Ukrainian).

Dovgan', N. B. (2013). Sravnitel'naja ocenka kolbasy varenoj vysshego sorta "Doktorskaja" raznyh proizvoditelej. Vestnik Omskogo gosudarstvennogo agrarnogo universiteta, 2(10), 50-53. https://cyberleninka.ru/article/n/sravnitelnaya-otsenkakolbasy-varenoy-vysshego-sorta-doktorskaya-raznyhproizvoditeley (in Russian).

Fursik, O. P., \& Strashynskyi, I. M. (2017). Kvalimetrychna otsinka orhanoleptychnykh pokaznykiv varenykh kovbas. Naukovyi visnyk LNUVMBT imeni S. Z. Gzhytskoho, 19(75), 72-75. doi: 10.15421/nvlvet7514 (in Ukrainian).

Ievtushenko, M. O. (2018). Porivnialnyi analiz yakosti kovbasnykh vyrobiv torhivelnykh marok "Khmelnytski delikatesy" ta "Iatran". Aktualni problemy veterynarnoi medytsyny: materialy mizhnarodnoi naukovo-praktychnoi konferentsii mahistrantiv, 22 lystopada 2018 r., Bila Tserkva, 2122 (in Ukrainian).

Kolesnyk, T. L., Kolesnyk, A. O., \& Yakovliev, I. O. (2014). Formuvannia spozhyvchykh vlastyvostei varenykh kovbas za pokaznykom bezpeky. Prohresyvni tekhnika i tekhnolohii kharchovykh vyrobnytstv restorannoho hospodarstva ta torhivli, 2(20), 304-314. http://nbuv.gov.ua/UJRN/Pt_2014_2_33 (in Ukrainian).

Koniak, I. V. (2012). Stan ta perspektyvy rozvytku rynku kovbasnykh vyrobiv v Ukraini. Visnyk Chernivetskoho torhovelno-ekonomichnoho instytutu. Ekonomichni nauky, 4, 168-174. http://nbuv.gov.ua/UJRN/Vchtei_2012_4_29 (in Ukrainian).
Nesterova, S. A., \& Moskvicheva, A. B. (2017). Analiz assortimenta i ocenka kachestva kolbasnyh izdelij na primere kolbasy "Doktorskaja". Sovremennye issledovanija osnovnyh napravlenij gumanitarnyh i estestvennyh nauk (sekcija "tehnologija produkcii i organizacija obshhestvennogo pitanija i tovarovedenija"): sbornik nauchnyh trudov mezhdunarodnoj nauchno-prakticheskoj konferencii, 2-3 marta 2017 g., Kazan', 372-378 (in Russian).

Poltoratskaia, A. (2018). Ukrainskyi rynok miasa i kovbasy: analiz. [Elektronnyi resurs]. https://koloro.ua/ua/blog/issledovaniya/ukrainskiyrynok-myasa-i-kolbasy-analiz.html (in Ukrainian).

Rakhman, M. S., Manhushev, D. V., \& Klimova, A. S. (2018). Analiz strukturnykh zrushen na vitchyznianomu ta zovnishnomu rynkakh miasa $\mathrm{i}$ miasoproduktiv v Ukraini. Ekonomika i suspilstvo, 18, 203-212. doi: 10.32782/2524-0072/2018-18-28 (in Ukrainian).

Romaniuk, T. M. (2019). Osoblyvosti otsinky konkurentospromozhnosti sosysok i sardelok. Visnyk studentskoho naukovoho tovarystva "VATRA" Vinnytskoho torhovelno-ekonomichnoho instytutu KNTEU, 77, 260-266 (in Ukrainian).

Sljoz, A. (2017). Analiz miasnoho i kovbasnoho rynku Ukrainy za 2016-2017 rik. [Elektronnyi resurs]. https://koloro.ua/ua/blog/issledovaniya/Analiz-miasnogoi-kolbasnogo-rinka-Ukrainu.html (in Ukrainian).

Tul'ceva, U. D. (2017). Sootvetstvie kachestva varenoj kolbasy doktorskaja s trebovanijami GOST R 521962011 ot proizvoditelej OOO "Berkuty" i OOO "Vostochnyj" Udmurtskoj Respubliki. Nauchnye trudy studentov Izhevskoj GSHA, 2(5), 309-311. https://www.elibrary.ru/item.asp?id=32396927 (in Russian).

Ushakov, F. O. (2017). Kontrol bezpechnosti ta yakosti kovbasnykh vyrobiv: Avtoref. dys.na zdobuttia nauk. stupenia kand. vet. nauk. Kyiv (in Ukrainian).

Varchenko, M. M., \& Herasymenko, Ye. V. (2019). Spozhyvcha ekspertyza tradytsiinoi ta suchasnoi tekhnolohii varenykh kovbas. Novitni tekhnolohii vyrobnytstva ta pererobky produktsii tvarynnytstva: Materialy naukovo-apktychnoi konferentsii studentiv. 18 kvitnia 2019 roku. Bila Tserkva, 46-48 (in Ukrainian).

Verbelchuk, T. V., \& Koshlan, Yu. T. (2016). Tekhnolohiia vyrobnytstva varenykh kovbas $\mathrm{V}$ umovakh TOV VTF "Marian" m. Zhytomyr. Tekhnolohiia vyrobnytstva i pererobky produktsii tvarynnytstva, 6, 123-124. http://ir.znau.edu.ua/ handle/123456789/7905 (in Ukrainian). 